\title{
Studies on Genomic DNA Stability in Aluminium-Maltolate Treated Aged New Zealand Rabbit: Relevance to the Alzheimer's Animal Model
}

\author{
Obulesu Magisetty ${ }^{\mathrm{a}}$, Dowlathabad Muralidhara Rao ${ }^{\mathrm{b}, \mathrm{c}}$, Shama Sundar N. M ${ }^{\mathrm{a}}$
}

\begin{abstract}
Background: Alzheimer's disease (AD) is a devastative neurodegenerative disorder. Lack of substantial animal model that can unravel molecular underpinnings has been a major lacuna which limited the understanding of the etiology of the disease in turn limiting the employment of potential therapeutic strategies to combat the disease for a few decades. Our studies for the first time provided substantial animal model and tattered the etiology of the disease at a molecular level.
\end{abstract}

Methods: In this study DNA was isolated from Hippocampus $(\mathrm{H})$, Midbrain (M) and Frontal Cortex (Fc) of control and aluminium maltolate (Al-M) treated aged New Zealand rabbit brain. DNA damage has been studied using Agarose gel electrophoresis, Ethidium Bromide (EtBr) binding and Melting temperature techniques.

Results: Al-M treated aged New Zealand rabbit's H and M showed higher DNA damage compared to corresponding controls, where as Fc showed mild DNA damage compared to corresponding controls.

Conclusions: This study tangibly provides substantial molecular level understanding of the disease in turn providing an adequate platform to streamline potential therapeutic strategies.

Keywords: Alzheimer's disease; Aluminium maltolate; Animal model; DNA damage

\section{Introduction}

Although adequate research has been progressing for a century, the understanding of the etiology of Alzheimer's

\footnotetext{
Manuscript accepted for publication August 19, 2009

${ }^{a}$ Department of Anatomy, JSS Medical College, Mysore, India

${ }^{b}$ Department of Biotechnology, Sri Krishnadevaraya University, Anantapur, India

'Corresponding author: mobulesu@rediffmail.com
}

doi:10.4021/jocmr2009.09.1265 disease (AD) has not been completely unraveled due to the lack of substantial animal model [1,2]. The biochemical events entailed in the neuronal cell loss are not clear till date $[1,3]$. The majority of the animal models worked till date could demonstrate single event expression such as extra cellular $A \beta$ deposition, intraneuronal neurofilamentous aggregation of proteins similar to neurofibrillary tangles, oxidative stress and apoptosis $[1,4]$. However, the intracisternal injection of aluminium maltolate (Al-M) into aged New Zealand rabbit replicates the neuropathological, biochemical and behavioural changes found in $\mathrm{AD}$ [1, 5-13]. Lovell et al reported DNA damage like single strand/double strand breaks, base specific oxidation like $\mathrm{G}^{*}$ specific oxidation [14-19]. Increased DNA oxidation has also been noticed in AD [2022]. A few studies have shown that DNA repair failure is a prominent feature in $\mathrm{AD}[23,24]$. The deterioration of the DNA repair system takes place with aging. Abnormal cell cycle regulation and/or accumulated DNA damage also leads to $\mathrm{AD}$ [25]. A few animal models were developed to study the genes responsible for this disease and the increase of specific transcripts [26]. The pathological events like hyperphosphorylation of tau, formation of neurofibrillary tangles, $A \beta$ deposition, were studied [27-29]. Introduction of $A \beta$ 1-42 into rabbits also provided animal model for $\mathrm{AD}$ [30].

Accumulation of DNA damage may also lead to AD [31]. Limited work has been done on DNA stability in this animal model so far. The present work has been carried out to unravel the molecular underpinnings of the disease pathology.

\section{Materials and Methods}

Maltol, $\mathrm{Al}$ (NO3)3. $9 \mathrm{H}_{2} \mathrm{O}$, Agarose, Ethidium Bromide $(\mathrm{EtBr})$, Hepes, Tris, Hepes and Tris buffers were purchased from Sigma Chemicals (USA). All other chemicals were of analytical grade and were purchased from Sisco Research Labs, Mumbai, India.

\section{Al-M preparation}

Al-M was prepared from maltol (3-hydroxy-2methyl- 
4H pyran-4-one) following the method of Finneagan [32]. Maltol and $\mathrm{Al}\left(\mathrm{NO}_{3}\right)_{3} .9 \mathrm{H}_{2} \mathrm{O}$ were mixed in 3:1 ratio. The $\mathrm{pH}$ was adjusted to 8.6 and heated for a few minutes. This aluminium-maltolate was used in the present study to understand the Aluminium's effect on genomic DNA. Aluminium complex is hydrolytically stable from $\mathrm{pH} 2.0$ to 12.0 . This complex enhances free Aluminium existence by $60-70 \%$ at neutral $\mathrm{pH}$ compared to any other inorganic or organic Aluminium complex.

Aluminium speciation chemistry is a complex phenomenon, hence to overcome this observation Aluminiummaltolate (Al-M) was used in the present investigation.

\section{Animal treatment and tissue processing}

All the animals were maintained in JSS animal house in single stainless steel cages. The experiments were done according to the institute's ethical committee and INSA guidelines. Aged Rabbits (3.5 to 4 yrs) from JSS Medical College Animal Colony were used. Six Rabbits were treated with Al-M intracisternally, while 6 rabbits with $0.9 \%$ saline injection were used as control. The intracisternal injection of Al-M into aged New Zealand rabbits was done as described by Savory $[11,33]$. The animals were decapitated and their brains were quickly removed, snap-frozen in $\mathrm{N}$ methylbutane at a temperature of $-40{ }^{\circ} \mathrm{C}$ with liquid nitrogen and stored at $-80{ }^{\circ} \mathrm{C}$ [34]. The anatomical localization of hippocampus, midbrain and cortical regions were accomplished using the designation outlined in an atlas of the rabbit brain and spinal cord [35].

\section{Isolation of DNA from brain tissue}

Genomic DNA from control and Al-M treated brain tissues were isolated by phenol-chloroform extraction protocol [36]. Tissue pieces were transferred into an autoclaved porcelain mortar and pestle (all glass wares, mortar, pestle were autoclaved before using them in order to avoid bacterial contamination). Liquid nitrogen was poured into the mortar and the tissue was frozen. Tissue was ground thoroughly with pestle with frequent additions of liquid nitrogen. Sufficient quantity of liquid nitrogen was poured into the mortar and swirled. Tissue homogenate was transferred into a sterile tube and the liquid nitrogen was allowed to evaporate. A sterile spatula was used to transfer the powdered tissue into a graduated tube. Lysis buffer $50 \mathrm{mM}$ Tris-Hcl (pH 8.0), 10 $\mathrm{mM}$ EDTA, and $100 \mathrm{mM} \mathrm{NaCl}$ was added into the tube along with $15 \mathrm{ug}$ per $\mathrm{ml}$ of proteinase $\mathrm{K}$ and $2 \%$ SDS final volume. One $\mathrm{ml}$ of lysis buffer was used for every $500 \mathrm{mg}$ of tissue. Lysis buffer was pre warmed, added proteinase $\mathrm{K}$ after first $2 \mathrm{~h}$. The homogenate was incubated at $37^{\circ} \mathrm{C}$ in a water bath for $12-16 \mathrm{~h}$ or over night. After the completion of incubation, the incubated lysate was transferred to an autoclaved $50 \mathrm{ml}$ conical flask and equal volume of tris-saturated phenol
( $\mathrm{pH}$ 8.0) was added and mixed thoroughly, either manually or mechanically for $10 \mathrm{~min}$. The lysate was centrifuged for $10 \mathrm{~min}$ at $10,000 \mathrm{rpm}$ at $13^{\circ} \mathrm{C}$. The supernatant was collected into a fresh autoclaved $50 \mathrm{ml}$ conical flasks and half volume of tris saturated phenol and chloroform: isoamyl alcohol was added and mixed thoroughly. One part phenol: 1 part chloroform $(\mathrm{C})$ and isoamylalcohol (IA) mixture $(\mathrm{C}: \mathrm{IA}=23: 1)$. Tris-saturated phenol was stored in amber colored bottles at low temperature to avoid oxidation of phenol. The supernatant and tris-saturated phenol-chloroform mixture was centrifuged at $5000 \mathrm{rpm}$ at $4{ }^{\circ} \mathrm{C}$.

The upper aqueous layer was collected into a fresh tube and $1 / 3$ volume of sodium acetate $(\mathrm{pH} 5.5)$ and equal volume of chilled absolute ethanol was added. DNA was precipitated by slowly swirling the tube manually. DNA was washed twice with $70 \%$ alcohol and once with absolute alcohol to remove excess salt and vacuum dried. The vacuum dried DNA was dissolved in $1 \mathrm{ml}$ of TE buffer $(10 \mathrm{mM}$ Tris-Hcl $1 \mathrm{mM}$ EDTA, pH 8.0). The DNA isolated from cells contains RNA also which was removed by digesting the preparation with RNAse enzyme. RNAse solution was kept in boiling water for 10 min so as to inactivate any DNAse because the RNAse may contain DNAse also. RNAse can also be added before Proteinase $\mathrm{K}$ treatment, and incubated at $37 \mathrm{oC}$ for 1 hour then start Proteinase K treatment (Add $1 \mu \mathrm{g}$ of RNAse/ml of lysis buffer for $30 \mathrm{~min}$ ).

\section{DNA concentration and purity}

DNA was quantified by recording its optical density at $260 \mathrm{~nm}$ by UV spectrophotometer. Absorbance of isolated DNA was read at $280 \mathrm{~nm}$. A260/A280 nm ratio was measured [36].

\section{Neutral agarose gel electrophoresis}

The genomic DNA integrity and damage was assessed by running neutral gel electrophoresis. The migration pattern in neutral gels reflects the double strand breaks present in the DNA. Neutral gels were electrophoresed on $1.5 \%$ agarose gels in Tris-acetate EDTA buffer $(\mathrm{pH} 8.0)$ at $4 \mathrm{~V} / \mathrm{cm}$ for $4 \mathrm{~h}$. Three ug of DNA was loaded in each well [36].

\section{EtBr binding to DNA and Scatchard plots}

The binding of EtBr to control and Al-M treated aged rabbits' brain DNA was measured in 0.01 M HEPES buffer ( $\mathrm{pH}$ 7.0) using Spectrofluorimeter (HITACHI, Japan) by taking 1:1 (w/w) DNA/EtBr before measuring fluorescence emission. DNA/EtBr solutions were excited at 535 $\mathrm{nm}$, and emission intensity was monitored at $600 \mathrm{~nm}$ using HITACHI F-2000 Fluorescence Spectrophotometer. The amount of EtBr bound to DNA was calculated using the independent binding equation of Scatchard [36, 37]. 


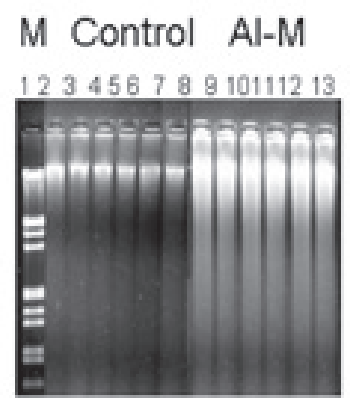

Figure 1. Indicating migration pattern of control and Al-M treated $\mathrm{H}$ DNA. Left lane $\mathrm{M}$ is Lambda DNA / EcoRI/HindIII double digest marker, 2-7 are control samples of $\mathrm{H}$ showing intact DNA where as $8-13$ showed diffused bands indicating DNA damage.

\section{Melting temperature profiles}

The melting curves for control and Al-M treated rabbits' brain DNA was carried out in 0.01 M HEPES buffer $(\mathrm{pH}$ 7.4) by recording $\mathrm{UV}$ absorbance at $260 \mathrm{~nm}$ at different temperatures $1{ }^{\circ} \mathrm{C} / \mathrm{min}$ using a Gilford Response II UV spectrophotometer fitted with thermostat control. The temperature range was between $25-95{ }^{\circ} \mathrm{C}$. Tm values were determined graphically from the absorbance versus temperature plots. The temperature point at which there is a $50 \%$ absorbance shift was taken as melting temperature (Tm) of the DNA sample. The precision of Tm values was estimated [36].

\section{Results}

\section{Behavioural features}

Al-M treated aged New Zealand rabbits showed following behavioural changes like reduced food intake, isolation behavior, forward head tilting, increased eye blinking, and hemiplegia.

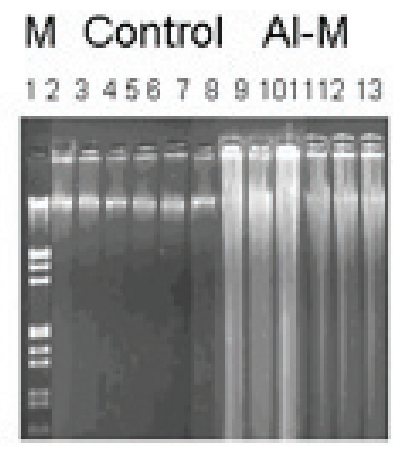

Figure 2. Indicating migration pattern of control and Al-M treated $M$ DNA. Left lane M is Lambda DNA / EcoRI/HindllI double digest marker, 2-7 are control samples of $M$ showing intact DNA where as 8-13 showed diffused bands indicating DNA damage.

\section{Control Al-M}

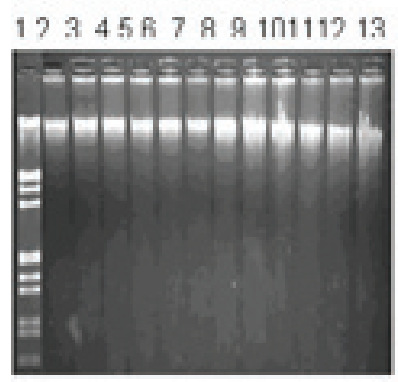

Figure 3. Indicating migration pattern of control and Al-M treated Fc DNA. Left lane M is Lambda DNA / EcoRI/HindIII double digest marker, 2-7 are control samples of Fc showing intact DNA, 8-13 are Al-M treated DNA.

\section{Agarose Gel electrophoresis}

DNA damage was observed by neutral agarose gel electrophoresis. Figure 1 shows neutral gels of genomic DNA from $\mathrm{H}$ of control and Al-M treated aged New Zealand white rabbits. Figure 2 shows neutral gels of genomic DNA from $\mathrm{M}$ of control and Al-M treated aged New Zealand white rabbits. Figure 3 shows neutral gels of genomic DNA from Fc of control and Al-M treated aged New Zealand white rabbits.

It has been observed that $\mathrm{H}$ demonstrated intense diffusion of the DNA bands indicating highest damage. The next highest damage has been observed in M. Frontal Cortex showed mild damage compared to other brain regions.

\section{Melting temperature profile}

The values mentioned in table 1 are the temperatures at which DNA is half denatured. The values are average of triplicates. The data in table 1 showed that the Tm is low for $\mathrm{Al}-\mathrm{M}$ treated $\mathrm{H}$ and $\mathrm{M}$ compared to the corresponding con-

Table 1. Melting Temperature (Tm) of DNA isolated from control and Al-M treated aged rabbits

\begin{tabular}{lll}
\hline Sample & Control & Al-M treated \\
\hline Hippocampus & $86.8 \pm 0.2$ & $74 \pm 0.3$ \\
Mid Brain & $89.7 \pm 0.7$ & $85.1 \pm 0.1$ \\
Frontal Cortex & $85.1 \pm 0.1$ & $82.7 \pm 0.7$ \\
& & \\
\hline
\end{tabular}

Values mentioned are as degree centigrade with means \pm SD. The point of $50 \%$ hyperchromic shift was calculated as $\mathrm{Tm}$. Al-M treated $\mathrm{H}$ and $\mathrm{M}$ showed considerable reduction in $\mathrm{Tm}$ compared to corresponding controls. 
Table 2. EtBr binding assay of of DNA isolated from control and $\mathrm{Al}-\mathrm{M}$ treated aged rabbits

\begin{tabular}{lll}
\hline Sample & Control & Al-M treated \\
\hline Hippocampus & $0.004 \pm 0.0003$ & $0.0008 \pm 0.0001$ \\
Mid Brain & $0.003 \pm 0.0002$ & $0.001 \pm 0.0002$ \\
Frontal Cortex & $0.0035 \pm 0.0005$ & $0.002 \pm 0.0001$ \\
\hline
\end{tabular}

EtBr bound per base pair of DNA from control and Al-M treated $H, M$ \& Fc were calculated using Scatchard plots. Values given are as mean of number of $\mathrm{EtBr}$ molecules bound per base pair of $D N A \pm S D$.

trols indicating considerable DNA damage or reduced stability. There was a little difference in the Tm of Fc indicating mild damage.

\section{EtBr binding studies}

The amount of EtBr molecules bound per base pair of DNA is represented in table 2. Two representative Scatchard plots of control and treated samples were drawn (Fig 4, 5, 6 for $\mathrm{H}, \mathrm{M}$ and $\mathrm{Fc}$ respectively). The values in table 2 are average of triplicates. Table 2 shows that Al-M treated $\mathrm{H}$ bound less EtBr compared to corresponding control indicating that DNA in this region is not intact. The next highest difference in EtBr binding has been observed in M. Mild difference in EtBr binding was observed in Fc.

\section{Melting temperature}

The melting temperature profiles of $\mathrm{H}, \mathrm{M}$, and Fc DNA isolated from control and Al-M treated rabbit brains were shown in Figure 7, 8, 9, respectively.

\section{Discussion}

Genomic DNA integrity plays pivotal role in the survival of an organism. The damage caused to its integrity shows deleterious effects on the health eventually leading to death. DNA repair capacity reduces with advancing age thus leading to the accumulation of the DNA damage. Oxidation of bases, strand breaks, formation of adducts, are the considerable factors in AD pathogenesis [15]. The animals tested so far could not provide substantial information on the etiology of the disease.

The animal models studied till date could demonstrate single pathological feature but failed to reciprocate the complete pathology of the AD. This lacuna made the insight into the pathology of the disease an uphill task for a few decades. $\mathrm{Al}$ is known to induce neurodegeneratiion although its role has been suspicious for a few decades. Since the advent of

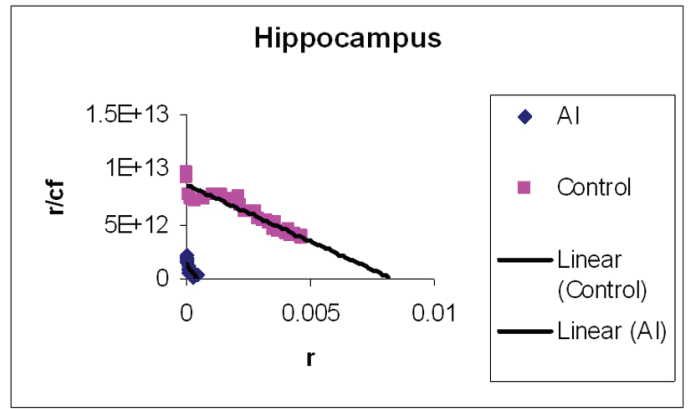

Figure 4. Showing Scatchard plot of ethidium bromide binding to DNA isolated from $\mathrm{H}$. EtBr concentrations were increased to a standard concentration of DNA in a $1 \mathrm{ml}$ reaction mixture. Fluorescence was obtained by keeping the excitation at 535 $\mathrm{nm}$ and emission at $600 \mathrm{~nm}$.

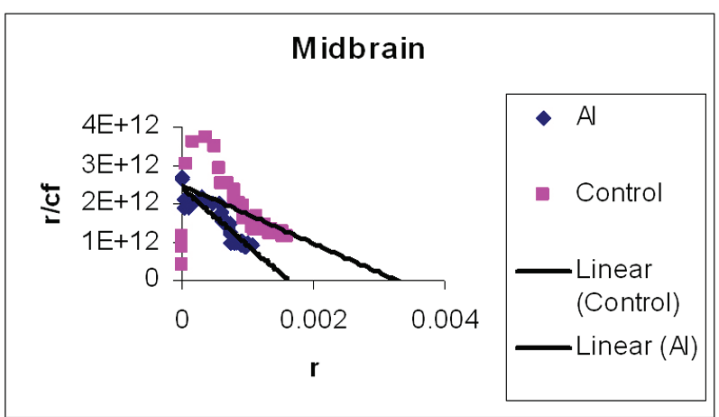

Figure 5. Showing Scatchard plot of ethidium bromide binding to DNA isolated from $\mathrm{M}$. EtBr concentrations were increased to a standard concentration of DNA in a $1 \mathrm{ml}$ reaction mixture. Fluorescence was obtained by keeping the excitation at $535 \mathrm{~nm}$ and emission at $600 \mathrm{~nm}$.

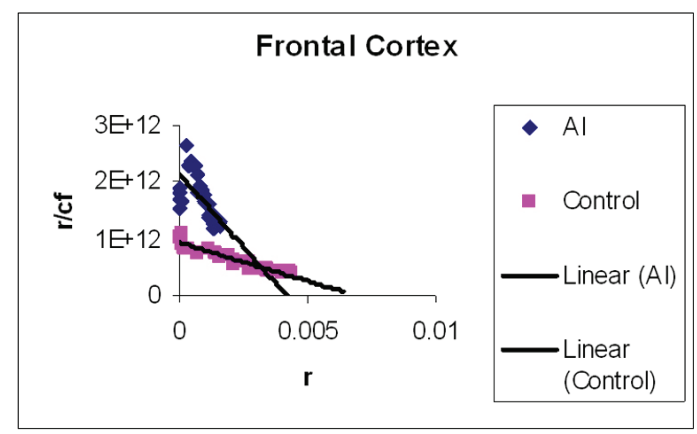

Figure 6. Showing Scatchard plot of ethidium bromide binding to DNA isolated from Fc. EtBr concentrations were increased to a standard concentration of DNA in a $1 \mathrm{ml}$ reaction mixture. Fluorescence was obtained by keeping the excitation at $535 \mathrm{~nm}$ and emission at $600 \mathrm{~nm}$.

neurotoxicological studies many Al salts like AlCl3 [38] have been employed which produced insoluble complexes at neutral $\mathrm{pH}$. Al-M has been chosen to be a neurotoxic agent for our studies, since maltolate aggravates the neurotoxicity 


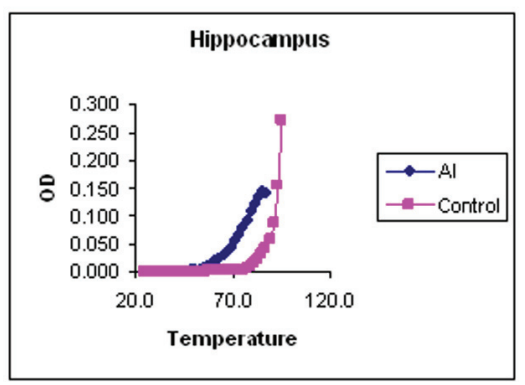

Figure 7. Indicating melting temperature profile of H DNA isolated from control and Al-M treated rabbit brains.

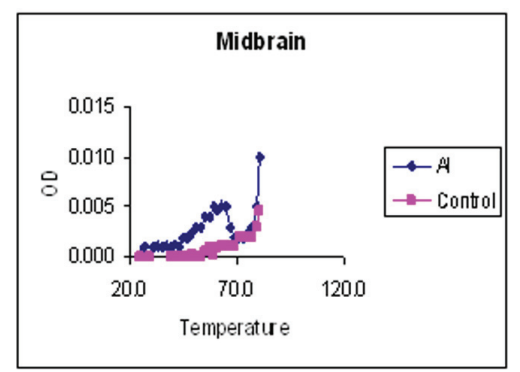

Figure 8. Indicating melting temperature profile of M DNA isolated from control and Al-M treated rabbit brains.

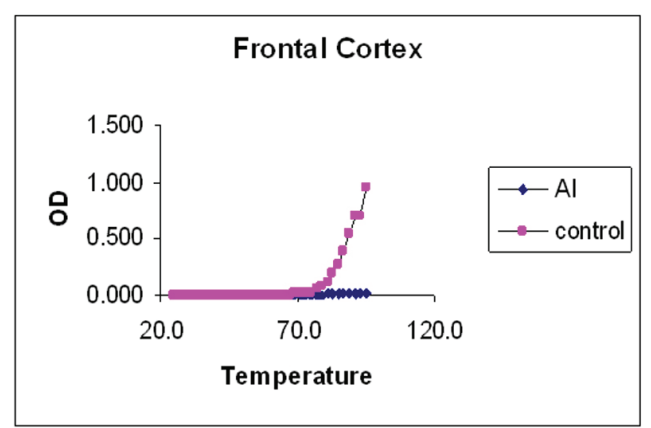

Figure 9. Indicating melting temperature profile of Fc DNA isolated from control and AI-M treated rabbit brains.

of the Al. Al-M induced rabbits mimic AD pathology. Al-M has following properties which made it an appropriate neurotoxin: 1 , very high metal solubility at $\mathrm{pH} 7.0 ; 2$, prominent kinetic restrictions to ligand exchange reactions in neutral solution [1]. This work accentuates the role of $\mathrm{Al}$ in neurodegeneration.

Our studies showed DNA damage in Al-M treated aged rabbits. Gel pattern showed the damage which is substantiated by $\mathrm{Tm}$ and $\mathrm{EtBr}$ values. Low $\mathrm{Tm}$ and less binding of
EtBr to the DNA emphasize the DNA damage [36].

Although adequate research has been going on for almost a century, the etiology of the $\mathrm{AD}$ has not yet been unraveled completely. The above observations emphasize the fact that there is severe damage in $\mathrm{H}$ which leads to the memory loss. The next highest damage has been noticed in $\mathrm{M}$. The damage observed in $\mathrm{Fc}$ is considerably less. These findings are in accordance with the AD pathology. DNA damage or stability reduction plays pivotal role in $\mathrm{AD}$. This work throws light on molecular understanding of pathology and tangibly gives substantial information about the etiology of the disease which stands as a suitable corner stone to streamline the potential therapeutic strategies.

\section{Acknowledgements}

This work is supported by Indian Council of Medical Research. M. Obulesu profoundly thanks Dr. KSJ Rao, Scientist, CFTRI, Mysore and Dr. K.H. Basavaraj for their support. He also sincerely thanks Indian Council of Medical Research for awarding Senior Research Fellowship.

\section{References}

1. Bharathi, Shama Sundar NM, Rao TSS, Ravid R, Rao KSJ. A new insight into Al-maltolate treated aged rabbit brain as Alzheimer's animal model. Brain Res Rev. 2006;52:275-292.

2. Colaco CA, Ledesma MD, Harrington CR, Avila J. The role of the Maillard reaction in other pathologies: Alzheimer's disease. Nephrol Dial Transplant 1996;11 Suppl 5:7-12.

3. Janus C, Westaway D. Transgenic mouse models of Alzheimer's disease. Physiol Behav 2001;73(5):873-886.

4. Shi Q, Gibson GE. Oxidative stress and transcriptional regulation in Alzheimer disease. Alzheimer Dis Assoc Disord 2007;21(4):276-291.

5. Ghribi O, DeWitt DA, Forbes MS, Arad A, Herman MM, Savory J. Cyclosporin A inhibits Al-induced cytochrome c release from mitochondria in aged rabbits. J Alzheimers Dis 2001;3(4):387-391.

6. Ghribi O, Herman MM, DeWitt DA, Forbes MS, Savory J. Abeta(1-42) and aluminum induce stress in the endoplasmic reticulum in rabbit hippocampus, involving nuclear translocation of gadd 153 and NF-kappaB. Brain Res Mol Brain Res 2001;96(1-2):30-38.

7. Ghribi O, Herman MM, Forbes MS, DeWitt DA, Savory J. GDNF protects against aluminum-induced apoptosis in rabbits by upregulating Bcl-2 and Bcl-XL and inhibiting mitochondrial Bax translocation. Neurobiol Dis 2001;8(5):764-773.

8. Ghribi O, DeWitt DA, Forbes MS, Herman MM, Savory 
J. Co-involvement of mitochondria and endoplasmic reticulum in regulation of apoptosis: changes in cytochrome c, Bcl-2 and Bax in the hippocampus of aluminum-treated rabbits. Brain Res 2001;903(1-2):66-73.

9. Ghribi O, Herman MM, Savory J. The endoplasmic reticulum is the main site for caspase-3 activation following aluminum-induced neurotoxicity in rabbit hippocampus. Neurosci Lett 2002;324(3):217-221.

10. Rao KSJ, Anitha S, Latha KS. Aluminium induced neurodegeneration in hippocampus of aged rabbits mimics AD. Alz Rep. 2000;3:83-88.

11. Savory J, Jagannatha KS Rao, Yue H, Philip R, Ledata, Mary M. Herman, Age-related hippocampal changes in Bcl3-2: Bax Ratio, Oxidative Stress, Redox-Active iron and apoptosis associated with Al induced neurodegeneration: Increased susceptibility with aging, Neurotoxicology. 1999;20:805-818.

12. Savory J, Ghribi O, Forbes MS, Herman MM. Aluminium and neuronal cell injury: inter-relationships between neurofilamentous arrays and apoptosis. J Inorg Biochem 2001;87(1-2):15-19.

13. Savory J, Herman MM, Ghribi O. Intracellular mechanisms underlying aluminum-induced apoptosis in rabbit brain. J Inorg Biochem 2003;97(1):151-154.

14. Gackowski D, Rozalski R, Siomek A, Dziaman T, Nicpon K, Klimarczyk M, Araszkiewicz A, et al. Oxidative stress and oxidative DNA damage is characteristic for mixed Alzheimer disease/vascular dementia. J Neurol Sci 2008;266(1-2):57-62.

15. Lovell MA, Markesbery WR. Oxidative DNA damage in mild cognitive impairment and late-stage Alzheimer's disease. Nucleic Acids Res 2007;35(22):7497-7504.

16. Martin LJ. DNA damage and repair: relevance to mechanisms of neurodegeneration. J Neuropathol Exp Neurol 2008;67(5):377-387.

17. Moreira PI, Nunomura A, Nakamura M, Takeda A, Shenk JC, Aliev G, Smith MA, et al. Nucleic acid oxidation in Alzheimer disease. Free Radic Biol Med 2008;44(8):1493-1505.

18. Mullaart E, Boerrigter ME, Ravid R, Swaab DF, Vijg J. Increased levels of DNA breaks in cerebral cortex of Alzheimer's disease patients. Neurobiol Aging 1990;11(3):169-173.

19. Wu J, Basha MR, Brock B, Cox DP, Cardozo-Pelaez F, McPherson CA, Harry J, et al. Alzheimer's disease (AD)-like pathology in aged monkeys after infantile exposure to environmental metal lead $(\mathrm{Pb})$ : evidence for a developmental origin and environmental link for AD. J Neurosci 2008;28(1):3-9.

20. Gabbita SP, Lovell MA, Markesbery WR. Increased nuclear DNA oxidation in the brain in Alzheimer's disease. J Neurochem 1998;71(5):2034-2040.

21. Lee SH, Kim I, Chung BC. Increased urinary level of oxidized nucleosides in patients with mild-to-moder- ate Alzheimer's disease. Clin Biochem 2007;40(1314):936-938.

22. Wang J, Xiong S, Xie C, Markesbery WR, Lovell MA. Increased oxidative damage in nuclear and mitochondrial DNA in Alzheimer's disease. J Neurochem 2005;93(4):953-962.

23. Francisconi S, Codenotti M, Ferrari-Toninelli G, Uberti D, Memo M. Preservation of DNA integrity and neuronal degeneration. Brain Res Brain Res Rev 2005;48(2):347351 .

24. Weissman L, Jo DG, Sorensen MM, de Souza-Pinto NC, Markesbery WR, Mattson MP, Bohr VA. Defective DNA base excision repair in brain from individuals with Alzheimer's disease and amnestic mild cognitive impairment. Nucleic Acids Res 2007;35(16):5545-5555.

25. Jacobsen E, Beach T, Shen Y, Li R, Chang Y. Deficiency of the Mre11 DNA repair complex in Alzheimer's disease brains. Brain Res Mol Brain Res 2004;128(1):1-7.

26. Tsujimura A, Matsuki M, Takao K, Yamanishi K, Miyakawa T, Hashimoto-Gotoh T. Mice Lacking the kf-1 Gene Exhibit Increased Anxiety- but not Despair-Like Behavior. Front Behav Neurosci 2008;2:4.

27. Johnson GV, Bailey CD. Tau, where are we now? J Alzheimers Dis 2002;4(5):375-398.

28. Morishima-Kawashima M, Hasegawa M, Takio K, Suzuki M, Yoshida H, Watanabe A, Titani K, et al. Hyperphosphorylation of tau in PHF. Neurobiol Aging 1995;16(3):365-371; discussion 371-380.

29. Chatterjee S, Sang TK, Lawless GM, Jackson GR. Dissociation of tau toxicity and phosphorylation: role of GSK-3beta, MARK and Cdk5 in a Drosophila model. Hum Mol Genet 2009;18(1):164-177.

30. McLarnon JG, Ryu JK. Relevance of abeta1-42 intrahippocampal injection as an animal model of inflamed Alzheimer's disease brain. Curr Alzheimer Res 2008;5(5):475-480.

31. Emil Adamec, Jean Paul Vonsatte, Ralph A. Nixon, DNA strand breaks in AD, Brain Res.1999;849:67-77.

32. Finneagan MM, Rettig S, Orvig CA, A Neutral water soluble Al complex of neurological interest, J Am Chem Soc. 1986;108:5033-5035.

33. Savory J, Huang Y, Herman MM, Reyes MR, Wills MR. Tau immunoreactivity associated with aluminum maltolate-induced neurofibrillary degeneration in rabbits. Brain Res 1995;669(2):325-329.

34. Strazielle C, Dumont M, Fukuchi K, Lalonde R. Transgenic mice expressing the human C99 terminal fragment of betaAPP: effects on cytochrome oxidase activity in skeletal muscle and brain. J Chem Neuroanat 2004;27(4):237-246.

35. Shek JW, Wen GY, Wisniewski HM. Atlas of the rabbit brain \& Spinal cord, Basel, Karger, (1986).

36. Hegde ML, Gupta VB, Anitha M, Harikrishna T, Shankar SK, Muthane U, Subba Rao K, et al. Studies on genomic 
DNA topology and stability in brain regions of Parkinson's disease. Arch Biochem Biophys 2006;449(12):143-156.

37. Scatchard G. The attraction of proteins for small mol- ecules \& ions. Ann NY Aca. Sci. US, 51, 1949;660-672. 38. Martin RB. The chemistry of aluminum as related to biology and medicine. Clin Chem 1986;32(10):17971806. 